\title{
Toxic effects of graphene and related materials on bacteria
}

\author{
Zhihui Huang ${ }^{1}$, Ning Gao ${ }^{1}$, Siyi Zhang ${ }^{1}$, Jianing Xing ${ }^{1}$ and Jing Hou ${ }^{1 \mathrm{a}}$ \\ ${ }^{1}$ MOE Key Laboratory of Resources and Environmental Systems Optimization, College of Environmental Science and \\ Engineering, North China Electric Power University, Beijing, 102206, PR China
}

\begin{abstract}
Graphene and related materials (GRMs) have been reported to have extensive applications in many areas. The widespread use of GRMs makes them inevitably enter the environment through various links causing adverse effects on organisms. Bacteria were representatively used to review the toxicological effects of GRMs on biological organisms in this paper. We comprehensively summarize the recent researches about negative effects of GRMs on bacteria. This is conductive to the evaluation of the ecological risk assessment of GRMs.
\end{abstract}

\section{Introduction}

Graphene is a two-dimensional material composed of carbon atoms arranged in a net of fused hexagons ${ }^{[1]}$, including single-layer graphene, few-layer graphene and multi-layer graphene ${ }^{[2]}$. Graphene, graphene oxide $(\mathrm{GO})$, reduced graphene oxide (rGO) and graphene-based materials formed by combining with various functional groups, organic compounds, metal ions, metal particles, etc. are collectively referred to as graphene and related materials(GRMs) ${ }^{[3-5]}$. GRMs have a wide range of potential applications in the fields of medicine, electronics, chemicals, water treatment, etc. because of its exceptional optical, mechanical and electrical properties $^{[6-8]}$. The widespread use of GRMs makes them inevitably enter the water environment through various links resulting in exposure of organisms to the GRMs.

There have been many studies reported the negative effects of GRMs on different types of living organisms and a great possibility of bioaccumulation ${ }^{[9,10]}$. Studies using the body burden factor (BBF) to evaluate the accumulation of $14 \mathrm{C}$-labeled graphene in E. coli, T. thermophila, D. magna, and D. rerio have showed that organisms exposed to graphene-containing culture medium have high potential of graphene accumulating ${ }^{[11]}$. Researches on the ecological safety of GRMs have increased rapidly and received extensive attention. However, these studies are chaotic and lacking in sorting and induction. Therefore, we summarized the characteristics and general patterns of toxic effects of different kinds of GRMs on bacteria, which were selected as representatives. The review of this article is worthy of reference for the future exploration of the environmental safety of GRMs.

\section{Toxicity characteristics of GRMs on bacteria}

\subsection{Common toxic effects of GRMs on bacteria}

Table 1 summarized the effects of GRMs on bacteria. On the whole, the antibacterial properties of GRMs has been recognized. They can reduce the cell viability, destroy cell wall integrity, inhibit the formation of bacterial biofilm, alter energy metabolism and cause oxidative damage on bacteria ${ }^{[12-15]}$. What's more, there are studies reported that its antibacterial effect is comparable to certain antibiotics ${ }^{[16]}$. In any case, more researches are needed about the antibacterial properties of different types GRMs to take advantage of this excellent feature. A disk diffusion test conducted by Kadiyala et al. showed that the diameter of inhibition zone (DIZ) of GO on gram-negative (E. coli) and gram-positive bacterial strain (S. aureus) are $19 \mathrm{~mm}$ and $21 \mathrm{~mm}$, respectively, which is bigger than gentamicin $(9.3 \mathrm{~mm}$ and $12.17 \mathrm{~mm}$ respectively $)^{[17]}$. But it is unsure whether GRMs exert greater effects on all the gram-negative bacteria than gram-positive ones. GRMs could be the promising materials for inhibiting resistant bacteria, because one of its antibacterial mechanisms is based on the physical damage. GO with concentrations higher than $10 \mathrm{mg} / \mathrm{L}$ could damage the resistant plasmids of E. coli HB101 consequently reduce its resistance to antibiotics ${ }^{[18]}$. Once GRMs were successfully used to inactivate various resistant bacteria, there will be a leap forward in the treatment of resistant bacteria. Among the influencing factors, the shape, size and surface coating etc. are factors that are relatively easy to regulate.

\footnotetext{
${ }^{\text {a }}$ Corresponding author: houjing@ncepu.edu.cn
} 


\subsection{Effect of surface modification on the toxicities of GRMs}

Surface modification of GRMs can both increase and decrease the toxicities of GRMs. Understanding the changes of toxic effects of surface modification is useful

Table 1. Toxic effects of different GRMs on different bacteria.

\begin{tabular}{|c|c|c|c|c|}
\hline GRMs & Species & Exposure condition & Efftcts & $\begin{array}{l}\text { Refe- } \\
\text { rence }\end{array}$ \\
\hline $\mathrm{Ag}-\mathrm{GO}$ & $\begin{array}{l}\text { Natural } \\
\text { aquatic } \\
\text { microorgani } \\
\text { sms }\end{array}$ & $\begin{array}{c}\text { Exposed to Ag-GO concentration of } 10,50, \\
\text { or } 100 \mathrm{mg} / \mathrm{L} \text { at mimic natural aquatic } \\
\text { environment }\end{array}$ & $\begin{array}{l}\text { Reduced enzymes activities; } \\
\text { Decreased nitrification rate; } \\
\text { ROS was generated continuously }\end{array}$ & [19] \\
\hline $\begin{array}{l}\mathrm{Cu}_{2} \mathrm{O}- \\
\text { Graphene }\end{array}$ & V. cholerae & $\begin{array}{l}\text { The bacteria culture medium was incubated } \\
\text { with } 100 \text { or } 300 \mu \mathrm{g} \text { contained } \mathrm{Cu} 2 \mathrm{O}- \\
\text { Graphene disc loaded at } 4^{\circ} \mathrm{C} \text { for } 24 \mathrm{~h}\end{array}$ & $\begin{array}{l}300 \mu \mathrm{g} \text {-DIZ: } 20 \mathrm{~mm} \\
200 \mu \mathrm{g} \text {-DIZ: } 14 \mathrm{~mm} \\
300 \mu \mathrm{g} \text {-DIZ: } 20 \mathrm{~mm}\end{array}$ & {$[20]$} \\
\hline $\begin{array}{l}\mathrm{Cu}_{2} \mathrm{O}- \\
\text { Graphene }\end{array}$ & S. pyogenes & $\begin{array}{l}\text { Incubated with } 100 \text { or } 300 \mu \mathrm{g} \text { contained } \\
\mathrm{Cu} 2 \mathrm{O}-\text { Graphene disc loaded at } 4^{\circ} \mathrm{C} \text { for } 24 \mathrm{~h}\end{array}$ & $\begin{array}{l}100 \mu \mathrm{g}-D I Z: 0 \mathrm{~mm} \\
200 \mu \mathrm{g}-D I Z: 14 \mathrm{~mm} ; \\
300 \mu \mathrm{g}-\mathrm{DIZ}: 22 \mathrm{~mm}\end{array}$ & [20] \\
\hline $\begin{array}{l}\text { AuNPs- } \\
\text { rGO-NC }\end{array}$ & E. coli & $\begin{array}{c}\text { Incubated with } 100 \pm 15 \mu \mathrm{g} \text { AuNPs-rGO- } \\
\mathrm{NC} \text { contained disk placed on at } 32^{\circ} \mathrm{C} \text { for } 24 \\
\mathrm{~h} \text { and incubated with } 10 \text { to } 100 \mu \mathrm{g} / \mathrm{L} \\
\text { AuNPs-rGO-NC in an orbital shaker } \\
\text { maintained at } 180 \mathrm{rpm} \text { at } 30^{\circ} \mathrm{C}\end{array}$ & $\begin{array}{l}\text { DIZ: } 33 \mathrm{~mm} ; \\
\text { AI: } 3.548 ; \\
\text { MIC: } 30 \mu \mathrm{g} / \mathrm{mL} \text {; } \\
\text { MBC: } 40 \mu \mathrm{g} / \mathrm{mL}\end{array}$ & {$[17]$} \\
\hline $\begin{array}{l}\text { AuNPs- } \\
\text { rGO-NC }\end{array}$ & B. subtilis & $\begin{array}{l}\text { Incubated with } 100 \pm 15 \mu \mathrm{g} \text { AuNPs- } \\
\text { rGO-NC contained disk placed on at } \\
32^{\circ} \mathrm{C} \text { for } 24 \mathrm{~h} \text { and incubated with } 10 \text { to } \\
100 \mu \mathrm{g} / \mathrm{L} \text { AuNPs-rGO-NC in an orbital } \\
\text { shaker maintained at } 180 \mathrm{rpm} \text { at } 30^{\circ} \mathrm{C}\end{array}$ & $\begin{array}{l}\text { DIZ: } 30 \mathrm{~mm} ; \\
\text { AI: } 2.323 \text {; } \\
\text { MIC: } 40 \mu \mathrm{g} / \mathrm{mL} \text {; } \\
\text { MBC: } 50 \mu \mathrm{g} / \mathrm{mL}\end{array}$ & {$[17]$} \\
\hline $\begin{array}{l}\text { AuNPs- } \\
\text { rGO-NC }\end{array}$ & S. aureus & $\begin{array}{l}\text { Incubated with } 100 \pm 15 \mu \mathrm{g} \text { AuNPs- } \\
\text { rGO-NC contained disk placed on at } \\
32^{\circ} \mathrm{C} \text { for } 24 \mathrm{~h} \text { and incubated with } 10 \text { to } \\
100 \mu \mathrm{g} / \mathrm{L} \text { AuNPs-rGO-NC in an orbital } \\
\text { shaker maintained at } 180 \mathrm{rpm} \text { at } 30^{\circ} \mathrm{C}\end{array}$ & $\begin{array}{l}\text { DIZ: } 29 \mathrm{~mm} ; \\
\text { AI: } 3.382 ; \\
\text { MIC: } 50 \mu \mathrm{g} / \mathrm{mL} \text {; } \\
\text { MBC: } 60 \mu \mathrm{g} / \mathrm{mL}\end{array}$ & {$[17]$} \\
\hline $\mathrm{GO}$ & B. subtilis & $\begin{array}{c}\text { Incubated with } 100 \pm 15 \mu \mathrm{g} \text { GO } \\
\text { contained disk placed on at } 32^{\circ} \mathrm{C} \text { for } \\
24 \mathrm{~h} \text { and incubated with } 10 \text { to } 100 \mu \mathrm{g} / \mathrm{L} \\
\mathrm{GO} \text { in an orbital shaker maintained at } \\
180 \mathrm{rpm} \text { at } 30^{\circ} \mathrm{C}\end{array}$ & $\begin{array}{l}\text { DIZ: } 21 \mathrm{~mm} ; \\
\text { AI: } 1.626 ; \\
\text { MIC: } 60 \mu \mathrm{g} / \mathrm{mL} \text {; } \\
\text { MBC: } 80 \mu \mathrm{g} / \mathrm{mL}\end{array}$ & {$[17]$} \\
\hline rGO & E. coli & $\begin{array}{c}50 \mu \mathrm{L} \text { rGO solution were placed into a } \\
\text { well with diameter of } 1 \mathrm{~cm}\end{array}$ & $\begin{array}{l}\text { DIZ: } 18 \pm 0.5 \mathrm{~mm} \\
\text { Cell wall integrity reduced } \\
\text { with increasing time }\end{array}$ & {$[15]$} \\
\hline $\mathrm{ZnO}-\mathrm{rGO}$ & E. coli & $\begin{array}{c}50 \mu \mathrm{L} \mathrm{ZnO-rGO} \text { solution were placed into a } \\
\text { well with diameter of } 1 \mathrm{~cm}\end{array}$ & $\begin{array}{c}\text { DIZ: } 28 \pm 0.7 \mathrm{~mm} ; \\
\text { A sudden decrease of integrity } \\
\text { after } 20 \mathrm{~min} \\
\end{array}$ & {$[15]$} \\
\hline GO & E. coli & $\begin{array}{l}\text { Dispersed GO was inoculated with bacteria } \\
\text { of } 70 \mu 1 \mathrm{l} 108 \mathrm{CFU} / \mathrm{ml} \text {, incubated at } 37^{\circ} \mathrm{C} \text {; } \\
\text { Bacteria of } 108 \mathrm{CFU} / \mathrm{ml} \text { were cultured on } \\
\text { nutrient agar plates supplemented with GO } \\
\text { of } 250 \mathrm{ppm}\end{array}$ & $\begin{array}{l}\text { MIC: } 125 \text { ppm; } \\
\text { Removal efficiency: about } 70 \%\end{array}$ & [21] \\
\hline GO & S. aureus & $\begin{array}{l}\text { Dispersed GO NPs was inoculated with } 70 \\
\mu 1108 \mathrm{CFU} / \mathrm{ml} \text { of the bacteria, incubated at } \\
37^{\circ} \mathrm{C}\end{array}$ & MIC: 225 ppm & [21] \\
\hline $\mathrm{G}-\mathrm{Fe}_{3} \mathrm{O}_{4}$ & E. coli & $\begin{array}{c}\text { Dispersed G-Fe3O4 NPs was inoculated } \\
\text { with } 70 \mu 108 \mathrm{CFU} / \mathrm{ml} \text { of the bacteria, } \\
\text { incubated at } 37^{\circ} \mathrm{C} \text {; Bacteria of } 108 \mathrm{CFU} / \mathrm{ml} \\
\text { were cultured on nutrient agar plates } \\
\text { supplemented with G-Fe3O4 of } 250 \mathrm{ppm}\end{array}$ & $\begin{array}{l}\text { MIC: } 100 \mathrm{ppm} \text {; } \\
\text { Removal efficiency: about } 92 \%\end{array}$ & [21] \\
\hline $\mathrm{G}-\mathrm{Fe}_{3} \mathrm{O}_{4}$ & S. aureus & $\begin{array}{c}\text { Dispersed G-Fe3O4 NPs was inoculated } \\
\text { with } 70 \mu 1108 \mathrm{CFU} / \mathrm{ml} \text { of the bacteria, } \\
\text { incubated at } 37^{\circ} \mathrm{C}\end{array}$ & MIC: 200ppm & [21] \\
\hline $\mathrm{rGO}-\mathrm{ZnO}$ & $\begin{array}{c}\text { K. } \\
\text { pneumonia }\end{array}$ & $\begin{array}{l}\text { RGO-ZnO nanocomposite was loaded }(20, \\
30,50 \mu \mathrm{L}) \text { in } 4 \mathrm{~mm} \text { diameter of agar wells, } \\
\text { incubated at } 38^{\circ} \mathrm{C} \text { for } 24 \mathrm{~h}\end{array}$ & DIZ: $14 \pm 0.44 \mathrm{~mm}$ & [22] \\
\hline $\mathrm{rGO}-\mathrm{ZnO}$ & $\begin{array}{c}B . \\
\text { thuringiensi } \\
s \\
\end{array}$ & $\begin{array}{l}\text { rGO-ZnO nanocomposite was loaded ( } 20, \\
30,50 \mu \mathrm{L}) \text { in } 4 \mathrm{~mm} \text { diameter of agar wells, } \\
\text { incubated at } 38^{\circ} \mathrm{C} \text { for } 24 \mathrm{~h}\end{array}$ & DIZ: $14 \pm 0.73 \mathrm{~mm}$ & {$[22]$} \\
\hline
\end{tabular}




\begin{tabular}{|c|c|c|c|c|}
\hline $\mathrm{rGO}-\mathrm{ZnO}$ & B. cereus & $\begin{array}{l}\text { rGO-ZnO nanocomposite was loaded }(20, \\
30,50 \mu \mathrm{L}) \text { in } 4 \mathrm{~mm} \text { diameter of agar wells, } \\
\text { incubated at } 38^{\circ} \mathrm{C} \text { for } 24 \mathrm{~h}\end{array}$ & DIZ: $15 \pm 0.55 \mathrm{~mm}$ & [22] \\
\hline rGO-ZnO & $\begin{array}{l}P . \\
\text { aerunginosa }\end{array}$ & $\begin{array}{l}\text { rGO-ZnO nanocomposite was loaded ( } 20, \\
30,50 \mu \mathrm{L}) \text { in } 4 \mathrm{~mm} \text { diameter of agar wells, } \\
\text { incubated at } 38^{\circ} \mathrm{C} \text { for } 24 \mathrm{~h}\end{array}$ & DIZ: $12 \pm 0.65 \mathrm{~mm}$ & [22] \\
\hline GO-Ag & E.coli & $\begin{array}{c}\text { Bacterial suspensions with different } \\
\text { concentrations of GO-Ag (from } 1.0 \text { to } \\
100.0 \mu \mathrm{g} / \mathrm{mL} \text { ) added were incubated at } \\
37^{\circ} \mathrm{C} \text { for } 18 \mathrm{~h}\end{array}$ & MIC: $0.01 \mathrm{mg} / \mathrm{mL}$ & [23] \\
\hline GO-Ag & S. aureus & $\begin{array}{c}\text { Bacterial suspensions with different } \\
\text { concentrations of } \mathrm{GO}-\mathrm{Ag} \text { (from } 1.0 \text { to } \\
100.0 \mu \mathrm{g} / \mathrm{mL} \text { ) added were incubated at } \\
37^{\circ} \mathrm{C} \text { for } 18 \mathrm{~h} \\
\end{array}$ & MIC: $0.17 \mathrm{mg} / \mathrm{mL}$ & [23] \\
\hline GO-Ag & E. coli & $\begin{array}{l}\text { Bacteria were cultured in connect with foils } \\
\text { coated with GO-Ag at } 37^{\circ} \mathrm{C}\end{array}$ & $\begin{array}{l}\text { Antibacterial activity: } 88.6 \% \\
\text { Membrane Integrity: } 66.3 \% \text {; } \\
\text { Enhanced ROS }\end{array}$ & [14] \\
\hline GO-Ag & S. aureus & $\begin{array}{l}\text { Bacteria were cultured in connect with foils } \\
\text { coated with } \mathrm{GO}-\mathrm{Ag} \text { at } 37^{\circ} \mathrm{C}\end{array}$ & $\begin{array}{l}\text { Antibacterial activity: } 79.6 \% \\
\text { Membrane Integrity: } 59.4 \% \text {; } \\
\text { Enhanced ROS }\end{array}$ & [14] \\
\hline $\begin{array}{l}\text { Spindle- } \\
\text { shaped GO }\end{array}$ & E. coli & $\begin{array}{l}\text { Cell solutions added spindle-shaped GO } \\
\text { inoculated at } 37^{\circ} \mathrm{C} \text { for } 12 \mathrm{~h} \text {; Put disks on } \\
\text { the bacteria contained agar at } 37^{\circ} \mathrm{C} \text { for } 12 \mathrm{~h}\end{array}$ & $\begin{array}{l}\text { MIC: } 125 \mu \mathrm{g} / \mathrm{mL} \\
\quad \text { R: } 15 \pm 0.2 \%\end{array}$ & [24] \\
\hline $\begin{array}{l}\text { Spindle- } \\
\text { shaped GO }\end{array}$ & $\begin{array}{c}S . \\
\text { typimurium }\end{array}$ & $\begin{array}{l}\text { Cell solutions added spindle-shaped GO } \\
\text { inoculated at } 37^{\circ} \mathrm{C} \text { for } 12 \mathrm{~h} \text {; Put disks on } \\
\text { the bacteria contained agar at } 37^{\circ} \mathrm{C} \text { for } 12 \mathrm{~h}\end{array}$ & $\begin{array}{l}\text { MIC: } 125 \mu \mathrm{g} / \mathrm{mL} \\
\quad \text { R: } 15 \pm 0.2 \%\end{array}$ & [24] \\
\hline
\end{tabular}

Caption: Diameter of inhibition zone (DIZ); Activity index (AI); Minimum inhibition concentration (MIC); Minimum bactericidal concentration (MBC); The normalized viability ratio (R)

Graphene oxide (GO); Graphene (G); AuNPs-rGO nanocomposite (AuNPs-rGO-NC); Reduced graphene oxide (rGO); Zinc oxide decorated rGO (ZnO-rGO)

for choosing appropriate types of modifier to achieve the specific purpose of toxicity regulation. The factors determining the modification effect include the kinds of surface coating and the ratio of GRMs to modifiers. Common types of modifying include metal or metal oxide nanoparticles, metal ion, inorganic salts and other organics. Generally speaking, the compound is more toxic when it is combined with a substance that itself is antibacterial ${ }^{[25,26]}$. For instance, GRMs decorated with $\mathrm{Au}-\mathrm{NPs}, \mathrm{Cu}-\mathrm{NPs}, \mathrm{Cu}_{2} \mathrm{O}$, curcumin or polyindole have stronger inhibitory effects than the bare GRMs ${ }^{[17,20,27-29]}$. This may be the synergy effect of GO and modifiers. But there are also exceptions. Unlike this enhanced toxicity, Gao et al. reported the decreased joint toxicity while investigating the combined toxicity of $\mathrm{GO}$ and heavy metal cation $(\mathrm{Me}(\mathrm{II}))\left(\mathrm{Cd}^{2+}, \mathrm{Co}^{2+} \text { and } \mathrm{Zn}^{2+}\right)^{[30]}$. The authors gave some reasons for this phenomenon like the adsorption of GO reduced the content of free $\mathrm{Me}(\mathrm{II})$, $\mathrm{Me}$ (II) weakened the sharp edges of GO and bacteria are difficult to assimilate the complexes. In other word, it is because the combination of graphene and $\mathrm{Me}(\mathrm{II})$ reduces the probability of $\mathrm{Me}$ (II) entering cells. At the same time, the deeper reason may be that $\mathrm{Me}(\mathrm{II})$ need to enter the inside of bacteria firstly and then bind to the biomacromolecules, while substances which have a synergistic effect with GRMs can engender toxic effects through contact with the surface of bacteria. The other factor is the ratio of GRMs to modifiers. The average growth inhibitory rate of $E$. coli for Graphene- $\mathrm{Fe}_{3} \mathrm{O}_{4}$ nanohybrid with Graphene/ $\mathrm{Fe}_{3} \mathrm{O}_{4}$ weight ratios of 1-1, 13 and $1-5$ at concentration of $250 \mathrm{mg} / \mathrm{L}$ are $75.6 \%$, $82.8 \%$ and $92.1 \%$, respectively ${ }^{[21]}$. But there is no research that has gone into the influence of the ratio of other coatings to GRMs on the antibacterial properties of composites, which deserves further research to get more information about the effect of composition ratio on antimicrobial properties.

\subsection{Effect of inherent properties of GRMs on its toxicities.}

Some inherent properties of GRMs such as size and morphology will affect its antibacterial characteristics. Generally speaking, materials with smaller size exert greater effects on organisms. Smaller-sized GO sheet showed stronger antibacterial property due to larger defect density, while measuring the antibacterial activity on GO-coated surface ${ }^{[31]}$. This could also be because the smaller-sized has a larger specific surface area with a stronger adsorption effect, and is easier to enter the organism accordingly. In term of morphology, wrinkled GO nanosheets with different roughness grade have different antibacterial capabilities, which is related to the relative dimension between the surface roughness grade and the bacterial size ${ }^{[32]}$. But, there is a lack of comparison of antibacterial properties between GRMs with the same size but wrinkled and smooth surfaces, respectively.

\section{Conclusion}

In general, there are many factors that contribute to the toxicities of GRMs on bacteria. Toxicities of GRMs with different purity, morphology, thickness, lateral dimension, surface charge and coating may vary greatly. 
So, we can select appropriate types of GRMs according to our needs in practical. GRMs with higher toxicity can be chosen in the process of sterilization and elimination of harmful algae, but for materials that are frequently or directly in contact with human beings, the GRMs with lower toxicity should be selected through optimization. The researches on the toxic effects of GRMs make great contributions to the utilization and environmental risk assessment of GRMs.

\section{References}

1. A.K. Geim, K.S. Novoselov, Nature Materials 6, 183 (2007)

2. A. Bianco, H.M. Cheng, T. Enoki, Y. Gogotsi, R.H. Hurt, N. Koratkar, T. Kyotani, M. Monthioux, C.R. Park, J.M.D. Tascon, et al., Carbon 65, 1 (2013)

3. S. Stankovich, D.A. Dikin, G.H.B. Dommett, K.M. Kohlhaas, E.J. Zimney, E.A. Stach, R.D. Piner, S.T. Nguyen, R.S. Ruoff, Nature 442, 282 (2006)

4. P. Wick, A.E. Gaume, M. Kucki, H.F. Krug, K. Kostarelos, B. Fadeel, K.A. Dawson, A. Salvati, E. Vazquez, L. Ballerini, et al., Angewandte ChemieInternational Edition 53, 7714 (2014)

5. V.C. Sanchez, A. Jachak, R.H. Hurt, A.B. Kane, Chem Res Toxicol 25, 15 (2012)

6. R.K. Shervedani, A. Amini, Electrochim Acta 173, 354 (2015)

7. K. Liu, J.J. Zhang, F.F. Cheng, T.T. Zheng, C. Wang, J.J. Zhu, J Mater Chem 21, 12034 (2011)

8. B. Nam, H.J. Lee, H. Goh, Y.B. Lee, W.S. Choi, J Mater Chem 22, 3148 (2012)

9. C.J. Lu, X.F. Jiang, M. Junaid, Y.B. Ma, P.P. Jia, H.B. Wang, D.S. Pei, Chemosphere 184, 795 (2017)

10. C. Wang, X.L. Chang, Q. Shi, X. Zhang, Environ Sci Technol 52, 12133 (2018)

11. S. Dong, T. Xia, Y. Yang, S. Lin, L. Mao, Environ Sci Technol 52, 541 (2018)

12. J. Chen, S. Li, J. Luo, Y. Zhang, W. Ding, Journal of Nanoscience and Nanotechnology 17, 186 (2017)

13. N. Yadav, A. Dubey, S. Shukla, C.P. Saini, G. Gupta, R. Priyadarshini, B. Lochab, Acs Omega 2, 3070 (2017)

14. S. Jaworski, M. Wierzbicki, E. Sawosz, A. Jung, G. Gielerak, J. Biernat, H. Jaremek, W. Lojkowski, B. Wozniak, J. Wojnarowicz, et al., Nanoscale Research Letters 13, (2018)

15. P.K. Sandhya, J. Jose, M.S. Sreekala, M. Padmanabhan, N. Kalarikkal, S. Thomas, Ceram Int 44, 15092 (2018)

16. K. Krishnamoorthy, M. Veerapandian, L.H. Zhang, K. Yun, S.J. Kim, The journal of physical chemistry C 116, 17280 (2012)

17. N.K. Kadiyala, B.K. Mandal, S. Ranjan, N. Dasgupta, Materials Science \& Engineering CMaterials for Biological Applications 93, 191 (2018)

18. M.T. Guo, G.S. Zhang, Chemosphere 183, 197 (2017)
19. K. Ko, M.J. Kim, J.Y. Lee, W. Kim, H. Chung, Sci Total Environ 651, 1087 (2019)

20. J. Athinarayanan, V.S. Periasamy, R. Krishnamoorthy, A.A. Alshatwi, Materials Science \& Engineering C-Materials for Biological Applications 93, 242 (2018)

21. A.N. Mahmoodabadi, A. Kompany, M. Mashreghi, Mater Chem Phys 213, 285 (2018)

22. R. Rajeswari, H.G. Prabu, Journal of Inorganic and Organometallic Polymers and Materials 28, 679 (2018)

23. J. Mohammadnejad, F. Yazdian, M. Omidi, A.D. Rostami, B. Rasekh, A. Fathinia, Eng Life Sci 18, 298 (2018)

24. L. Zhong, H. Liu, M. Samal, K. Yun, Journal of Photochemistry and Photobiology B-Biology 183, 293 (2018)

25. K. Prasad, G.S. Lekshmi, K. Ostrikov, V. Lussini, J. Blinco, M. Mohandas, K. Vasilev, S. Bottle, K. Bazaka, K. Ostrikov, Sci Rep 7, (2017)

26. L. Ouyang, Y. Deng, L. Yang, X. Shi, T. Dong, Y. Tai, W. Yang, Z.-G. Chen, Macromol Biosci 18, (2018)

27. C.H. Deng, J.L. Gong, G.M. Zeng, P. Zhang, B. Song, X.G. Zhang, H.Y. Liu, S.Y. Huan, Chemosphere 184, 347 (2017)

28. F. Bugli, M. Cacaci, V. Palmieri, R. Di Santo, R. Torelli, G. Ciasca, M. Di Vito, A. Vitali, C. Conti, M. Sanguinetti, et al., Interface Focus 8, (2018)

29. M. Shoeb, M. Mobin, M.A. Rauf, M. Owais, A.H. Naqvi, Acs Omega 3, 9431 (2018)

30. Y. Gao, X. Ren, J. Wu, T. Hayat, A. Alsaedi, C. Cheng, C. Chen, Environmental Science-Nano 5, 362 (2018)

31. S. Liu, M. Hu, T.H. Zeng, R. Wu, R. Jiang, J. Wei, L. Wang, J. Kong, Y. Chen, Langmuir 28, 12364 (2012)

32. F. Zou, H. Zhou, D.Y. Jeong, J. Kwon, S.U. Eom, T.J. Park, S.W. Hong, J. Lee, Acs Applied Materials \& Interfaces 9, 1343 (2017) 